\title{
Navigating the market of welfare services: The choice of upper secondary school in Sweden
}

\section{Torbjörn Hjort}

School of Social Work

Lund University

Email: Torbjorn.hjort@soch.lu.se

\author{
Alexandru Panican \\ School of Social Work \\ Lund University \\ Email: Alexandru.panican@soch.lu.se
}

\begin{abstract}
Due to increased market orientation and deregulation, welfare services in Sweden have taken on the form of market-based services. The body of research on deregulation and privatization is quite substantial regarding the implications of this kind of development. However, studies of the actual process of how choices are made are less common. This article discusses the implications of greater freedom of choice for Swedish citizens in diverse socioeconomic situations, focusing on factors that limit opportunities for choice. Deregulation and the increasing number of alternatives affect the relationship between the citizen and the welfare state in several ways. The Swedish school system is used here as an example of an empirical field. The analytical focus of the article consists of two different kinds of restrictions on choice: structure-based and agencybased. One conclusion is that both affluent and underprivileged citizens have limited choices. Another conclusion is that social
\end{abstract}


citizenship, when freedom of choice is stimulated, can reproduce and even increase social and ethnic segregation. An additional potential consequence is that, when we consider social rights in their tangible form, the development of greater freedom of choice is focused increasingly on the consumer's range of choices and less on the quality of the service offered.

Keywords: citizenship, deregulation, freedom of choice, education, welfare services

\section{Introduction}

The aim of this article is to discuss the conditions and prerequisites for citizens' choices of welfare services within the context of the Swedish welfare state. The deregulation of public sector-based welfare services towards an increased number of private and non-profit alternatives should be understood from the perspective of the previous situation, where the state was the dominant provider. This means that greater freedom of choice in selecting welfare services is a relatively new phenomenon for Swedish citizens. We want to discuss what freedom of choice regarding welfare services implies for citizens in diverse socioeconomic situations, not just for groups who are considered as disadvantaged, which is the usual focus of welfare deregulation studies. We analyse the actual opportunities for choice, which means that we focus on substantial, rather than formal, freedom of choice. We employ the Swedish school system as an example, focusing on the upper secondary school system, an area where marketization has increased and where the pupils and parents are offered a range of alternatives concerning school and education. Education is one of the most significant factors regarding the development of an individual's well-being (Vinnerljung et al., 2010) since it strongly influences future opportunities in the labour market (Olofsson \& Panican, 2008).

In recent decades, education has increasingly become a matter of personal choice for citizens of Sweden, and this is also the case for navigating the market for other welfare services. The greater number of options for welfare services creates new opportunities, but also places new demands upon citizens. The body of research on deregulation and privatization is quite substantial concerning the

NJSR - Nordic Journal of Social Research

Vol. 5, 2014 
implications of this development. However, studies of the actual process of selection - for instance, choosing a healthcare or education provider - are less common. Increased freedom to choose also changes the relationship between the citizen and the welfare state, moving it towards what can be considered a consumer relation.

The responsibility for obtaining a product of good quality that is also individually adapted is increasingly being placed upon citizens. This transformation has been framed in neoliberal terms, promoting concepts like freedom and individuality in contrast with a welfare state burdened by bureaucracy (Eriksen \& Weigård, 1999; Harvey, 2005).

One argument behind increased deregulation has been that welfare services should be better tailored to individual needs and preferences. A wider range of alternatives is thought to increase the competition between providers and, consequently, the efficiency and quality of welfare services (Eriksen \& Weigård, 1999; Norén, 2010). This belief, inspired by the neoliberal agenda, challenges the idea of citizenship as it is understood in the context of the type of welfare state that has prevailed in Sweden. Citizenship within this kind of welfare state is based on two main principles: (i) citizens have equal opportunities to participate in welfare services, and (ii) government, at both the national and local levels, is considered the guarantor of equality regarding welfare services. Among citizens in Sweden there is a high degree of trust in the capacity and ambition of the welfare state to deliver premium services to all citizens, irrespective of income or ability to pay (e.g. Svallfors, 2004). This ideological welfare context implies that an increased freedom of choice also places greater demands upon citizens. Having the knowledge and competence to be able to compare different alternatives is an example of one such demand. Greater freedom of choice does not represent, by definition, any 'paradise of personal discretion' (Offer, 2006:357).

Our main interest in this article is to analyse how the citizen relates to and manages the process of choosing. How does the citizen approach the role of consumer in considering welfare services, in this case with a special focus on the upper secondary school system? Choosing an education, considering both content and provider, is a complex task that includes consequences and dimensions that are difficult to foresee. The literature on deregulation of welfare services gives us some ideas of the complexity, including opportunities as well as restrictions regarding the process of choosing. In this article we discuss the process of choosing in the context of this literature.

NJSR - Nordic Journal of Social Research 


\section{Method and material}

This article is based on a level of abstraction driven by theoretical reasoning about the importance, for citizens in diverse socioeconomic situations, of increasing the freedom to choose from among welfare services. When speaking of socioeconomic situation, we are referring to factors such as one's status in the housing and labour markets, education and income. This article is also a review of existing research and attempts to organize the various critiques of freedom of choice. We synthesize previous research by constructing two forms of restrictions concerning freedom of choice. The literature review is primarily based on literature of deregulation in the educational sector in a Nordic context and in an international context mainly focused on UK. We also use government publications reflecting government bills and Swedish government official reports to provide background information on the changes that the educational system has undergone through the introduction of increased opportunities of choice regarding both school and educational programme.

\section{Review of previous research on freedom of choice}

Research on how individuals and groups make selections based upon different preferences is well represented in the body of research on consumer behaviour and on marketing (Bettman et al., 1998; Alba \& Hutchinson, 2000; Trentman, 2007). The majority of research on freedom of choice has been in commodity markets and services, whereas we focus on welfare services. Regarding an increased freedom of choice of school education, the research has focused primarily on the effects of the deregulation of the school system for school representatives and, in particular, for citizens from disadvantaged social backgrounds (Ball, 2003, 2006, 2007; Bunar, 2010a). In contrast, we aim to discuss the process of how choices are made by children and parents in diverse socioeconomic situations.

Research on freedom of choice in relation to welfare services such as health care (Blomqvist, 2005), school systems (Ball, 2003; Bunar, 2009, 2010a, 2010b, 2010c; Norén, 2010) and social care (Norén, 2003; Szebehely \& Trygdegård, 2007) is comprehensive, nationally and internationally (Blomqvist, 2004). Both international research (Ball, 1994, 2006, 2007; Ball et al., 2007; Gewirtz et al., 1995; Ambler, 1998; Hatcher, 1998; Reay \& Ball, 1997) and national research (Kjellman, 2001; Damgren, 2002; Skawonius, 2005; Johnsson, 2004) show that the opportunities to choose are not equally distributed; some groups have more of the resources, knowledge and skills required to navigate among different alternatives. The research also

NJSR - Nordic Journal of Social Research 
indicates that an increase in opportunities to select a school and educational programmes augments segregation (Richardsson, 2004; Bunar, 2005; Lund, 2006; Kallstenius, 2009; Olofsson, 2010). Where the state and the municipality once stood as guarantors for equal access to welfare services, these services have now become more customized. The educational system in Sweden is characterized by privatization, deregulation and liberalization; pupils and parents choose from diverse public and private educational options. Schools have become providers of education in a competitive market. Reforms towards greater choice in secondary education in Sweden show that a broader range of options consolidates existing differences that follow patterns of class, parents' education, income and position in the labour market (Bunar, 2009; Englund, 1993; Arnman et al., 2004; Broady, 2001; Lund, 2007). At the same time, the research concludes that greater freedom of choice also leads to a less segregated and stigmatized school (Gorard \& Fitz, 2000; Gorard et al., 2001).

Those who advocate an expanded freedom of choice argue that welfare services can be customized to better accommodate individual needs and preferences. But these arguments for individualized citizenship tend to disregard the structural aspects that are likely to reinforce existing social norms. The consumer is also governed by collective and structural factors. In his research, Bourdieu (1984) demonstrates how taste, style and consumption are closely connected to social class, concluding that class-based social distinctions are recreated through consumption. Factors such as class, gender, education level, ethnicity, age and income define the "right" choice when selecting a product or service. A citizen faces collective expectations for the choices he or she makes. There seems to be an equality principle within one's own social group, in the sense that groups select the options that are consistent with their own group's preferences (Johnsson, 2004).

It should be stressed that even if we, to some extent, can be influenced in our selection of, for example, pasta or shoes, these choices are to be regarded as freer than the regulated choices we make concerning welfare services. When freedom of choice is regulated, the actual selection is more limited, because politicians and government agencies strive to offer choices within a range of what is considered reasonable in relation to the public interest and policy objectives (Norén, 2003, 2010). Market mechanisms also impose limitations on freedom of choice, since the fundamental objective of market-based activities is profit. Welfare service providers select customers based on a specific profile, making it more difficult for other customers to obtain equivalent services, which is a process known as 'skimming the cream' (Bunar, 2009).

NJSR - Nordic Journal of Social Research

Vol. 5, 2014 
Choosing a school and an education requires resources and capital (Bourdieu, 1986) such as knowledge, access to information, contacts and understanding of the educational system. The resource-poor or 'capital-poor' (Bunar, 2001) do not have the same opportunities to manage a greater range of options as those who are well established or well-off. It turns out that freedom of choice has more to do with competition based on segregation, symbolism, beliefs and traditions than with competition based on the quality of education provided by a school (Bunar, 2008). Equality, as the central value of citizenship, tends to be replaced by the ambition of equivalence that provides greater freedoms but less regard for pupils' and parents' ability to achieve those freedoms (Dovemark, 2007). As earlier noted, however, the focus of research thus far has mainly been on resource-poor, or underprivileged, groups.

\section{Theoretical starting points}

We use citizenship as an analytical framework to increase knowledge of how citizens, in this case children and parents choosing between upper secondary schools, are affected by a neoliberal concept of citizenship that is dominant in the political and administrative systems in Sweden.

Citizenship can generally be understood as a theoretical-analytical term, as a political conceptual tool to explain individual membership in a political community or as lived experience capturing a range of issues articulated in a citizen's daily practices (Lister et al., 2007). In our study, it is relevant to discuss citizenship as lived experience since we emphasize citizens' opportunities regarding how choices are made. This analytical starting point also necessitates an inclusion of the relationship between the citizen and the welfare state in the analytical model. This kind of relationship is regulated by citizenship rights (Marshall, 1992). Furthermore, we focus on social rights as these rights determine the redistributive process, public interventions and institutional arrangements to provide welfare services in the Nordic countries (Esping-Andersen, 1990, 1999; Kvist et al., 2012; Kautto et al., 2001; Kildal \& Kuhnle, 2005).

We refer, thusly, to citizenship rights of a legal nature. Marshall (1992) makes a distinction between civil, political and social rights. These rights are the basis for the concept of modern citizenship and have gradually evolved over the last three centuries: civil rights in the 18th century, political rights in the 19th century and social rights in the 20th century. Equality is a fundamental principle of citizenship rights: all

NJSR - Nordic Journal of Social Research

Vol. 5, 2014 
citizens must be able to enjoy the same rights. Social rights should not only ensure a minimum of social security, but also the right 'to live the life of a civilized being according to the standards prevailing in the society' (Marshall, 1992:8). Examples of social rights are benefits related to health care, social welfare, economic security for diverse groups and education. The right to education constitutes 'a genuine social right of citizenship' (Marshall, 1992:16).

The most imprecisely formulated are social rights, causing them to be the most debated and contested citizenship rights (Bottomore, 1992). Social rights are relative while political and civil rights are absolute. Political and civil rights are used as a protection against the state, while social rights delineate the responsibilities of the welfare state to protect the individual against social risks. This means that citizenship rights affect the nature of the relationship between the citizen and the welfare state in different ways (Eriksen \& Weigård, 1999; Westerhäll, 2002).

Social rights, which build the core of the welfare state, are based on the principles of solidarity and universality (Eriksen \& Weigård, 1999). Citizens can benefit from social rights through various human service organizations. Professionals from health care, social services and education are primarily responsible for the implementation of social rights, in accordance with the welfare state's social assignments. In this process of attaining social rights, the individual risks becoming a passive client, deprived of decision-making power and put in a position of accepting 'one-size-fits-all' services. The client is exposed to a process of de-individualization, relying on the competence and good will of professionals and, thereby, compelled into the role of passive receiver of social benefits. In order to preclude a paternalistic social system and to improve client status by emphasizing the importance of respect for the client's autonomy and their right to selfgovernance, the role of client has gradually been changed to the role of customer by involving individual service recipients in the decisionmaking process. But this role change has also been brought about in order to create social services of high quality based on effective use of resources. The relationship between citizens and social service institutions is increasingly influenced by the neoliberal values that dominate the organization of, and current thinking about, welfare policy. In the last few decades, there has been a sharp increase in the privatization and deregulation of welfare services, which have subsequently taken the form of market-based services. The citizen, taking on the role of customer, has been empowered through a greater freedom of choice of social services. Reflecting the active, obligatory participation of individual service recipients in shaping social benefits and choosing social service providers, agencies have

NJSR - Nordic Journal of Social Research 
adapted themselves to their demands. Social service agencies must embrace market mechanisms, following a customer-oriented approach in which individualizing models of services increases the power of attraction when competing for customers on the market of welfare services (Eriksen \& Weigård, 1999).

Citizenship as lived experience requires an additional clarification. Citizenship regulates the legal, formal relationship between the individual and the state through citizenship rights. This relationship is the basis for formal citizenship (thin citizenship). Each right, however, is largely a result of ideological notions. The content of citizenship rights is negotiated within the political arena. An example is the political right to vote, which arises from negotiations as to who should have this right and when this right can be exercised. In different contextual circumstances, implementation of rights requires negotiation. The same right may manifest itself in different ways, depending on the citizen's ability to invoke his or her rights and the official interpretation of the same. Preceding the interpretation of citizenship rights according to law and their implementation is a process involving negotiation based on prevailing sociocultural norms. The standards and attitudes of public, legal, political and private life are socialized and reproduced through these negotiations. Thus, negotiation shapes sociocultural citizenship (thick citizenship) (Panican, 2007).

In our study we assume formal citizenship when we describe the changes in the Swedish school system. The formal relationship between citizens and the welfare state has moved towards a more customer-oriented relationship between the individual and the welfare services. This part of the study comprises the descriptive part of our work. In the analytical portion, we will discuss the existing conditions and prerequisites for freedom of choice in the context of the Swedish welfare state, from a sociocultural citizenship perspective. This means that we will analyse the substantial, rather than the formal, freedom to choose. This perspective is important in studies that have citizenship as the theoretical starting point because '[...] citizenship must be understood as a contextualized concept and lived experience' (Lister et al., 2007:6).

The period after the Second World War has been characterized as a time of sociocultural citizenship based on an egalitarian social spirit. The core of this spirit is equal citizenship anchored in solidarity for underprivileged groups (Voet, 1998). Since the early 1980s, the egalitarian spirit has been gradually replaced in favour of a neoliberal ideology with freedom of choice, competition, accountability and flexibility as basic principles. The Reagan and Thatcher politics, in the

NJSR - Nordic Journal of Social Research 
US and the UK (New Right) respectively, are often mentioned as significant factors in this development (Wagner, 2004; Harvey, 2005). Universal equality is exchanged for equivalence privileges in the sense that all citizens have the same freedom of choice when it comes to welfare services: everyone has the right to choose an education, pension fund and from among various forms of care. According to the concept of neoliberal rights, the idea of equal conditions and the equality of reciprocity between citizens moves towards freedom of choice in order to carry out one's own life project. At the same time, governance is delegated to the local level. Power has been increasingly decentralized, leading to a market adjustment and the liberalization of welfare services (Lister et al., 2007; Florin et al., 2007). According to neoliberal ideology, the success of this system is dependent on the development of the active and autonomous 'citizen-consumer' who is socially, economically, politically and culturally competent (Trentmann, 2007; Aberbach \& Christensen, 2005; Clarke, 2007; Mitchell, 2003; Hvinden \& Johansson, 2007; Roberts, 2008).

In an education context, such an ideal necessitates that pupils receive an adequate school education that conforms to the current spirit of citizenship in society (Ravitch, 2010). Pupils should acquire proficiency in what neoliberal ideology considers 'real knowledge'. This is defined as information that prepares pupils for a knowledgeintensive working life characterized by rapid changes in skill requirements in the wake of new technologies and the need for language skills due to greater internationalization (Gandin \& Apple, 2003). According to this logic, the 'education industry' has to 'get smart and get real' (Kenway et al., 2007:2).

The makeup of social rights is collectively negotiated within the political arena, while market adjustment has, as shown, led to depoliticization of social citizenship. This means that a citizen's willingness, ability and position in society are crucial for the implementation of social rights. We wish to emphasize that the opportunity to claim and exercise social rights, not citizen rights as a concept in itself, is changing.

\section{Elementary and secondary school in Sweden}

The educational system in Sweden underwent major changes in the 1990s. These changes were implemented with the explicit purpose of increasing the efficiency and quality of school education. School reforms have promoted free market principles and decentralized

NJSR - Nordic Journal of Social Research

Vol. 5, 2014 
decision-making, giving municipalities and individual schools the right to determine the local curriculum (Government Bill 1990/91:85, Swedish Government Official Report 1997:121). This decentralization was followed by an additional school reform granting greater freedom for the establishment of private schools with municipal funding (Government Bill 1991/92:95).

Before the deregulation of schools, private alternatives were few and directed towards certain groups of pupils, mostly from the economic elite. It was more or less taken for granted that children and young adults in Sweden received their educations from public schools. Deregulation in the 1990s, has, among other things, resulted in the replacement of a more detailed set of rules and regulations by performance-based and goal-driven outcomes. The curricula for compulsory schooling and upper secondary schools follow neoliberal ideas: the management of performance and personalization of education via variable content as opposed to regulatory control of school education and uniformity in content. Substantial aspects of school activities are determined locally. The freedom to shape education at the local level is combined with freedom of choice in education.

One of the aims of the independent school reform of 1992 was to redistribute resources. Independent schools would receive municipal grants up to 85 per cent of the individual pupil allowance (Government Bill 1991/92:95). In the 2009/10 school year, the number of pupils who chose an independent school was 12 per cent of the total pupil volume in primary schools. During the same school year, there were 741 independent schools, as compared to just over 100 in the $1992 / 93$ school year. At the secondary level, the proportion of pupils studying in independent schools was 22 per cent in the 2009/10 school year (The Swedish National Agency for Education, 2011).

The development of an increased range of choices is not solely a case of providing a greater number of options when choosing between public or independent schools. In Sweden, an additional market of education has emerged within the public sector. Public schools can hence face the same challenges as independent schools, exposed to competition on a market where those who fail to recruit pupils will meet difficulties in receiving public funding (Richardsson, 2004).

Thus a neoliberal market discourse emerges: humanistic values are viewed as a key principle of education, and the equivalence of knowledge and access to education are being challenged by market motives, through which profit margins and competition between schools are becoming important factors for the educational system.

NJSR - Nordic Journal of Social Research 
This, however, is not the main focus of our discussion; our main focus is instead the pupils' and parents' freedom of choice of schools and education.

\section{Possible restrictions on choice}

The process of choosing from among different alternatives opens up opportunities to choose an alternative that can increase the probability that the specific service is tailored to the individual's own preferences and needs (Norén, 2010). However, as the literature has shown, this process of choosing also includes dimensions that restrict the opportunities to make a fairly independent choice. In this section we problematize the process of choosing and discuss some restrictions that affect the choice of an education program and provider. There are several ways to approach the question of restrictions on choosing. We suggest two types of constraints that, in different ways, hamper or thwart the selection process. The first one - structural restrictions focuses on causes that can be defined or understood as restrictions arising from societal structures and can be considered as external in relation to the individual. Examples of this type of hindrance are a lack of information and/or knowledge of alternatives, geographical barriers, ethnicity and class. Such restrictions reflect the way opportunities and possibilities are distributed and can partly be seen as a consequence of how market dynamics contribute to an already unequal distribution of opportunities regarding choice among diverse groups. These hindrances are sometimes more explicit, and appear as 'closed doors', and at other times are more discreet.

Agency-based restriction - the second type of restriction - builds upon the analytical framework of Bourdieu, or more precisely, his concept of habitus (Bourdieu, 1984). Habitus is basically defined as the way people behave in different settings and contexts. Bourdieu considers habitus class-based and as being reproduced in an unconscious way. This perspective can be viewed as more agency-based, focusing on dimensions that explain why some prefer a certain school or programme. That is, agency-based restriction is founded on ideas of how a citizen, dependent upon aspects like sociocultural acceptance, is expected to act. Even if the concept of habitus has structural connotations, we suggest that individuals, in this context, can be considered as agents who make their own choices. This analytical tool implies that the citizen, in different ways, is directed in the process of choosing when several options are considered inappropriate, even if these options are seen as attractive to the individual. This type of restriction is often expressed and interpreted as if the choice is a real and rational one.

NJSR - Nordic Journal of Social Research

Vol. 5, 2014 


\section{Structure-based restrictions}

Personal desire to choose from among alternative schools and programmes may indeed exist. However, due to various restrictions, actual opportunities to choose may be lacking. One structural barrier could be geography. For example, schools with highly qualified staffs and good performance records are often located in affluent areas far away from socially marginalized neighbourhoods (Arnman \& Jönsson, 1986; Bunar, 2010b). Attractive schools are thus out of reach for disadvantaged groups, as the range of alternatives is limited due to time constraints or travel expenses. In this way, freedom of choice can reinforce geographical segregation concerning education alternatives. However, overcoming this obstacle is not necessarily a response to greater freedom of choice; a citizen may simply have 'geographical luck' and live in an area that has developed into a wealthy district. However, the rhetoric promoting the growing range of alternatives points to opportunities, made available through an increased freedom of choice, to counteract geographical barriers.

Another type of barrier is the pedagogical/didactical methodology used in schools. The form and content of education are sometimes directed only to pupils with specific cultural and social capital. The actual opportunities for choice are limited to one single school, or to one type of school that coincides with the pupil's sociocultural capital (for empirical examples see Dovemark, 2007; Bunar, 2009).

Freedom of choice is also blind to the citizen's own actions. Freedom of choice follows the logic that all citizens are equal regardless of class, ethnicity, gender, sexuality, ability, competence and cultural and social capital. Yet choice does not take place '... in a social vacuum. Choosing a school other than the nearest one requires knowledge of educational alternatives and how other schools work, knowledge that is often unevenly distributed socially. The real opportunities are often very different among diverse groups of parents in a socially stratified society' (Arnman et al., 2004:31, our translation). The lack of knowledge needed to exercise freedom of choice can be a barrier to the disadvantaged, who do not always have the necessary tools regarding knowledge, time, status and resources (Broady, 2001; Swedish Government Official Report, 2000:39). Disadvantaged groups are not necessarily poor or socially marginalized. Through a variety of social constraints, financially well-off groups can also be included in the category of disadvantaged in this context.

Self-image and family values and networks, as well as social conditions, can make it more difficult to manage information about different options; the options available can be unfamiliar. The

NJSR - Nordic Journal of Social Research

Vol. 5, 2014 
disadvantaged have to choose between different schools and educational alternatives in competition with the highly educated. Yet the structural conditions are different: in these cases freedom of choice may be described as a selective mechanism that strengthens social and ethnic segregation (Bunar, 2009, 2010a). These barriers have also been explored in an international context where similar freedom of choice exists; see Peters (2001) on choice in the rapidly changing educational system in New Zealand, as well as studies of problematic choice reforms within the US-American educational system (Young \& Clinchys, 1992; Ravitch, 2010) and Ball's (2003) studies on the same conditions in the UK.

Difficulties associated with freedom of choice could result in abandoning the process of choosing altogether. Ball (2003) distinguishes between 'cold knowledge' - more formal information provided by schools - and 'hot knowledge'. Ball suggests that the middle class prefer 'hot knowledge', such as information gleaned from informal conversations about evaluations of schools, or gossip and rumours discussed within their network. This type of information is often dominated by symbolism that can only be interpreted by those within the same class (Johnsson, 2004). The shared social capital within this social category allows one to communicate and absorb information in a way that perpetuates class positions. Like-minded middle-class people, for example, can conclude that the range of schools does not include suitable alternatives that meet their educational needs (Lund, 2006). In this case, one is forced into a passive role. In the absence of suitable alternatives, there is a risk that no choice is made - something that could be considered a form of not being able to choose.

Another obstacle that is relevant is the fact that the opportunity to choose from among alternatives may be largely unknown, especially among immigrants (Dahlstedt, 2007; Bunar, 2008). This lack of awareness can be attributed to language barriers or lack of cultural competence, which make it difficult to absorb information about school choice. Also, school administrators might withhold information about options in order to keep potential pupils or keep out those that the school does not deem desirable (Bunar, 2009).

It is not only market-based mechanisms that can create hindrances and barriers related to the process of choosing. Such obstacles can also arise as a result of governmental policy. Upper secondary education is voluntary; individuals may choose not to study at this level. However, in reality, opting out is discouraged. There are individuals who prioritize work and choose not to study at all, but there are few employers who want to hire young adults without upper

NJSR - Nordic Journal of Social Research 
secondary level qualifications. Such 'unskilled' jobs are often advertised at employment offices. In interviews with representatives of municipal and governmental authorities in a small municipality, characterized by a high density of self-employed persons, the findings suggest that there is a demand for unskilled labour. Nonetheless, those interviewed argued that discouraging upper secondary level education is unthinkable. Several interviewees refused to recommend unskilled labour jobs to young unemployed persons despite a right to opt out of upper secondary level education. The same normative attitude, that considers a capable workforce as one with skills obtained from upper secondary education, prevails in several municipalities (Panican, 2013). In addition, not only do government agencies more or less coerce youngsters to study at upper secondary level, they also promote choices of education within a range of what is considered as reasonable in relation to public interest and policy objectives (Norén, 2003; 2010).

Another aspect that affects the freedom of choice is that alternatives are directed, in more or less sophisticated ways, towards increasing or reducing a citizen's ability to select a particular option (Peters, 2001; Lund, 2007). Representatives from schools can make it difficult to choose, or persuade potential pupils and parents to not choose a particular school or educational programme. It is not just the parents and pupils who choose the school, but also the school that chooses its' pupils. According to a study conducted by Skawonius (2005), '...the headmasters made [...] informal agreements with each other to keep the children of foreign origin in "immigrant schools" [...] with the argument that these schools have the competence to work with them. The headmasters also decided where pupils were placed among their respective institutions' (2005:327, our translation). The same study provided empirical examples of how headmasters neglected to inform some parents of alternatives, or how they attempted to make decisions without including parents. In this context, it is also important to mention the principle of proximity (the importance of pupils attending schools in their own neighbourhoods) as a means to reduce the demand on attractive schools. Occasionally, under this principle, pupils from areas outside of the local school's catchment area sometimes from 'problem' areas - are excluded from the selection process (Damgren, 2002; Hohnen \& Hjort, 2009).

These different aspects of hindrance and barriers are important to take into consideration when the transition from citizen to consumer is discussed. Principles such as equality and solidarity are challenged by market-based mechanisms such as segmentation, competition, and flexibility. Even if there are positive aspects of increased freedom of choice, this must be problematized with regard to the principal

NJSR - Nordic Journal of Social Research 
differences in the relations between, on the one hand, customer and provider and, on the other hand, the citizen and the welfare state.

\section{Agency-based restrictions}

There seems to be an idea of a rational citizen who can make sagacious choices based on quality. The 'right' choice is not merely an instrumental and strategic choice focusing on matching the pupil's ability and interests to educational content and future labour market opportunities. It can also include various external factors such as '... pupil status (how many pupils from the domestic Swedish population there are at a school) and neighbourhood status, "the reputation of the neighbourhood"' (Bunar, 2005:77, our translation).

As previous research suggests, making the 'right' choice also means adapting to, and relating with, the sociocultural norms that shape the acceptable alternatives for various socioeconomic groups. In the literature on freedom of choice and education, Bourdieu's concept of habitus - the socialized and reproduced subjectivity of the individual is often emphasized (Johnsson, 2004; Dovemark, 2007). Different social groups distinguish themselves by the choices they make and thus reproduce the social order. Conformity with prevailing expectations governs the choices made: 'The educational background of the parents is thus the most critical factor in school choice' (Skawonius, 2005:17, our translation). Pupils with well-educated parents are expected to choose theoretical programmes that prepare them for university studies, while children of less-educated parents are expected to choose vocational programmes (Arnman et al., 2004). Johnsson (2004) suggests that individual preferences combined with external expectations create the perception of a rational choice among diverse groups. Strategically and socioculturally correct choices may at times coincide, but, in failing to do so, may also emphasize the gap between the alternatives.

The usual focus of works related to this theme is on how disadvantaged groups are affected by the increasing freedom to choose. One of our main findings in this paper can broaden the understanding of the transformation from client to consumer, which is an important issue for all citizens regardless of their socioeconomic position. Also, the alternatives for well-educated and resource-rich groups tend to be restricted. The same is true about less-educated groups with limited resources. A pupil can break out of this generated conformity, but does so at the risk of being labelled as deviant, regardless of socioeconomic group. A doctor's child who chooses an automotive vocational programme tends to violate established social

NJSR - Nordic Journal of Social Research

Vol. 5, 2014 
norms. Making the 'right' choice means choosing from the options associated with social norms, which are based on similarities within a social group. It can be assumed that citizens with higher socioeconomic status may to be more likely to make independent choices and go against the tide, while the socioeconomically underprivileged citizens are more apt to make choices that are in line with expectations. The former group may well be in a position that makes it easier to justify choices that defy social norms.

Pupils that are performing at a high level may also have some difficulties in choosing educational programmes. They may be able to choose whatever they want, but perhaps others intend for them to be doctors or lawyers, while they may be most interested in an artistic education; for example dance. In a recently completed study, results indicated that there were two categories of pupils that seemed to experience the most difficulties regarding choice. On one hand were pupils with weak academic results from relatively disadvantaged families and, on the other hand, pupils with good academic qualifications from well-educated families. The first group's problems seemed to be caused by difficulties decoding information. For the other group, managing a substantial range of alternatives that included not only the educational programme they wanted to choose, but also that which they were expected to choose, was problematic. The second group seemed to be worried about closing doors in relation to future career possibilities (Hjort, Hjärpe \& Panican, 2013).

The tendency to choose in accordance with, and not against, expectations reveals a limitation in what is intended to represent freedom of choice for all citizens. Despite the fact that the institutionaland policy-based arrangements of comprehensive schooling have increasingly been replaced by new alternatives, the reproduction of sociocultural norms remains (Dovemark, 2007; Olofsson, 2010; Dahlstedt, 2007). In the rhetoric promoting freedom of choice, differences and inequalities are attributed to citizens' choices and not to societal structures. Whether or not the freedom to choose changes the problems accorded to the citizen by inequality in the previous educational system is a subject for debate. Freedom of choice involves the risk of perpetuating inequality among all social strata. From this perspective, making the 'right' choice restricts the freedom of choice, since 'right' bears different meanings for different social groups. Equality prevails within a group, implying the assumption, and continuation, of inequality between groups.

Additionally, examples of agency-based restrictions can include individuals who abstain from exercising freedom of choice; those who oppose the increasing marketization of welfare services and on

NJSR - Nordic Journal of Social Research 
principle refuse to choose a school, for example. The reason behind this point of view could be the idea that public schooling is an expression of solidarity and social justice as well as a tool to reduce class divisions. Perhaps there is no interest on the part of the individual in educational alternatives or alternative schools. The choice of school is passively delegated to municipal officials. This could be the case even if the assigned school does not meet the child's skill and personal developmental needs (Damgren, 2002).

A combination of structural and individual obstacles exists, in the sense that options can be presented or described in an incomprehensible way for those less familiar with the school system. The selection process is conducted in a way that is difficult for individuals to understand, using complex information to describe the alternatives.

Agency-based restrictions emphasize important issues in a process of choosing. The idea of the independent individual with competence to choose in accordance with personal preferences is challenged by previous research results indicating that the individual is interwoven in a web of values and perceptions constituting the 'right' choice. A choice deemed as individual-based can thus be questioned.

\section{Conclusion and discussion}

The transformation of the relationship between the citizen and the welfare state, with the aim of improving the position of the individual in attaining social rights, is a complex process. The goal is that the individual will be empowered to participate to an increasing extent in shaping social benefits. However, these good intentions can be problematized, as there seem to be different types of constraints, such as market logic and socioeconomic structures, which influence the process of choosing.

The citizen is forced to assume greater responsibility in choosing welfare services. Instead of playing the role of recipient, the citizen is viewed as a consumer of services. When schooling for a child fails to meet expectations, it is no longer primarily the problem of the welfare state that provided a defective service. Rather, this becomes the responsibility of the parents, who made an inadequate choice. The question is how citizens, who to varying degrees have power over the limitations discussed above, can be regarded as responsible and selfregulating members of society. One conclusion that can be drawn from this article is that when we consider social rights in their explicit

NJSR - Nordic Journal of Social Research 
form, we are increasingly assessing the consumer's ability to choose while focusing less on the quality of the services rendered.

A greater range of alternatives is meant to enhance both competition between and the quality of services, and also to better address citizens' specific needs. Critics have previously argued against a government monopoly stating, for example, that monopoly circumstances attempt to create services that suit all ('one-size-fitsall'), while implying that such services will actually suit none. These arguments often promote the idea that a greater share of welfare services should be market-driven. Despite this rationale, there remains a strong support for public welfare services (Svallfors, 2004). Educational reform has mainly taken place in recent decades, and we have a fairly limited knowledge of attitudes towards it. An important aspect of this reform is the fact that the welfare state relinquishes responsibility for guaranteeing citizens equal access to qualitatively acceptable welfare services. As discussed in this article, there are various reasons why citizens find themselves in problematic situations in which they are forced to choose and must invest more time and energy to gain access to welfare services. This applies to many different types of citizens, including those who are highly skilled, unskilled, and disadvantaged.

The research reviewed in this article suggests that sociocultural citizenship is increasingly anchored in neoliberal rhetoric, indicating a shift in responsibility from the state to the civil and private spheres. In recent decades, there has also been a shift in favour of the market and towards increasingly placing on the individual the responsibility to ensure that citizenship rights provided by the (welfare) state are materialized. The citizen is expected to act on, choose, apply for or otherwise exercise his or her right to the freedoms the state provides. Through the manifestation of social rights based on freedom of choice, equality within one's own social group is reproduced, while inequality between such groups persists. It appears that social citizenship reinforces social and ethnic segregation via the freedom of choice that is deeply rooted in the concept of social rights.

The concept of modern citizenship strives to abolish inequality between groups. Modern citizenship is complemented by the principle of universal equality: all citizens are equal in status. The Swedish welfare state, which includes extensive social citizenship, is traditionally based on the belief that citizens should have the same opportunities to receive welfare services and that the state and local governments should guarantee equal welfare services. There appears to be a risk that greater freedom in choosing welfare services produces inequality between groups in different socioeconomic

NJSR - Nordic Journal of Social Research 
positions with social and ethnic segregation as tangible consequences. In the neoliberal market-based discourse that dominates sociocultural citizenship, the principle of universal equality is actually transformed into equal freedom of choice.

Regarding the actual opportunity to choose, citizenship rights are based on the idea that there should be universal equality of access to and opportunity for utilization of welfare services. Since the individual, in the role of customer, has an increased responsibility for monitoring and exercising his or her rights, we believe that the principle of universal equality is being challenged. All citizens have a formal right to a range of welfare services. That means that the state has guaranteed equality from a quantitative perspective: everyone has the same formal rights to the same welfare services. However, the opportunities to utilize these services are not equally distributed, because of the knowledge and ability required. In addition, socioeconomic structures can hamper or thwart the process of choosing; what can be understood as a free choice can also be seen as predestined by dimensions such as class and ethnicity. As we have shown, not all citizens have the same conditions and opportunities for making choices. In addition to these factors, we also want to emphasize how institutional arrangements can govern the distribution of alternatives. This occurs when welfare-service administrators prioritize their own interests instead of the principle of universal equality. In the context of this study, this means that not everyone receives the same offer of alternative schools and educational programmes.

This article emphasizes two issues for further study: the first concerns the development of the relationship between citizens and welfare services towards one in which the citizen takes on the role of customer. The second issue introduces sociocultural citizenship as an expression of public opinion. The extent to which the marketization of welfare services reflects a general change in attitudes can be debated (Svallfors, 2004; Calzada \& del Pino, 2008). Does the marketization of education reflect prevalent sociocultural norms? This development raises questions about the construction and understanding of sociocultural citizenship and the implications for the citizen. 


\section{References}

Aberbach, J. D., \& Christensen, T. (2005). Citizens and consumers: An NPM dilemma. Public Management Review, 7(2), 225-245.

Alba, W., \& Hutchinson, W. J. (2000). Knowledge calibration: what consumers know and what they think they know. Journal of Consumer Research, 27(2), 123-156.

Ambler, J. S. (1998). Who benefits from educational choice? Some evidence from Europe. In E. Cohn (Ed.), Market approaches to education (pp. 353-379). Oxford: Elsevier Science.

Arnman, G., \& Jönsson, I. (1986). Olika för olika. [Differently for different] Lund: Arkiv.

Arnman, G., Järnek, M., \& Lindskog, E. (2004). Valfrihet: fiktion och verklighet.[Freedom of choice - fiction and reality] Uppsala: Uppsala University.

Ball, S. J. (1994). Education reform. Buckingham: Open University Press.

- - . (2003). Class strategies and the education market. London: Francis \& Taylor.

- - . (2006). Education policy and social class. London \& New York: Routledge.

- - - (2007). Education Plc. London \& New York: Routledge.

Ball, S. J., Goodson I. F., \& Maguire, M. (Eds.). (2007). Education, globalization and new times. London: Routledge.

Bettman, J. R., Luce, M. F., \& Payne, J. W. (1998). Constructive consumer choice processes. Journal of Consumer Research, 25(3), 187-217.

Blomqvist, P. (2004). The choice revolution: privatization of Swedish welfare services in the 1990s. Social Policy \& Administration, 38(2), 139-155.

- - . (2005). Privatiserad sjukvård: politisk lösning eller komplikation? [Privatization in health care: a political solution or complication?] Socialvetenskaplig Tidskrift, 12(2-3), 169-189.

Bottomore, T. (1992). Part II: Citizenship and Social Class, Forty Years On. In T.H. Marshall \& T. Bottomore, Citizenship and social class, (pp. 55-93). London: Pluto Press.

Bourdieu, P. (1984). Distinction. London: Routledge. 
- - . (1986). Kultursociologiska texter. [Cultural sociological texts] Stockholm: Salamander.

Broady, D. (2001). Gymnasieskolan och eliterna. [Upper secondary school and elites] Pedagogiska magasinet, 2(1), 56-61.

Bunar, N. (2001). Skolan mitt i förorten. [School in the middle of the suburb] Stockholm: Symposium.

- - . (2005). Valfrihet och anti-segregerande åtgärder. [The freedom of choice and the anti-segregation measures] Utbildning \& Demokrati, 14(3), 75-96.

- - . (2008). Bakgrund - om forskningsstudien, de mångkulturella innerstadsskolorna. [Background - about this research study, the multicultural inner city schools] In Valfrihet, integration och segregation i Stockholms grundskolor [Freedom of choice, integration, and segregation in Stockholm's primary schools]. Stockholms stad.

- - - (2009). När marknaden kom till förorten. [When the market came to the suburb] Lund: Studentlitteratur.

- - - (2010a). Choosing for quality or inequality: current perspectives on the implementation of school choice policy in Sweden. Journal of Education Policy, 25(1), 1-18.

- - - (2010b). The geographies of education and relationships in a multicultural city: enrolling in a high-poverty, low-achieving school and choosing to stay there. Acta Sociologica, 53(2), 141-159.

- - - (2010c). The controlled school market and urban schools in Sweden. Journal of School Choice, 4(1), 47-73.

Calzada, I., \& del Pino, E. (2008). Perceived efficacy and citizens' attitudes toward welfare state reform. International review of administrative sciences, 74(4), 555-574.

Clarke, J. (2007). Unsettled connections - Citizens, consumers and the reform of public services. Journal of Consumer Culture, 7(2), 159-178.

Dahlstedt, M. (2007). I val(o)frihetens spår. Segregation, differentiering och två decennier av skolreformer. [In the traces of (un)freedom of choice. Segregation, differentiation and two decades of school reforms] Pedagogisk Forskning i Sverige, 12(1), 20-38.

Damgren, J. (2002). Föräldrars val av fristående skolor. [Parental choice of independent schools] Malmö: Malmö Högskola.

Dovemark, M. (2007). Ansvar: hur lätt är det? [Responsibility: how easy is it?] Lund: Studentlitteratur. 
Englund, T. (1993). Utbildning som 'public good' eller 'private good'. [Education as a 'public good' or 'private good'] Uppsala: Pedagogiska institutionen.

Eriksen, E.O., \& Weigård, J. (1999). Fra statsborge til kunde: Kan relasjonen mellom innbyggerne og det offentlige reformuleres på grunnlag av nye roller? [From citizen to customer: Can the relationship between inhabitants and the government be reformulated on the basis of new roles?] In E.O. Eriksen (Ed.) Kommunikativ ledelse - om verdier og styring $i$ offentlig sektor [Communicative leadership - on values and governance in the public sector] (pp. 183-208). Bergen: Fagbokforlaget.

Esping-Andersen, G. (1990). The Three Worlds of Welfare Capitalism. Cambridge: Polity Press.

- - - (1999) Social Foundations of Postindustrial Economies. Oxford: Oxford University Press.

Florin, C., Elgán, E., \& Hagemann, G. (2007). Den självstyrande medborgaren? Ny historia om rättvisa, demokrati och välfärd. [The self-governing citizen? New history about justice, democracy and welfare] Stockholm: Institutet för Framtidsstudier.

Gandin, A. L., \& Apple, M. W. (2003). Educating the state, democratizing knowledge. In M. Apple (Ed.), The state and the politics of knowledge (pp. 193-219). New York: Routledge.

Gewirtz, S., Ball, S. J., \& Bowe, R. (1995). Markets, choice and equity in education. Buckingham: Open University Press.

Gorard, S., \& Fitz, J. (2000). Markets and stratification: a view from England and Wales. Educational Policy, 14(3), 405-428.

Gorard, S., Fitz, J. \& Taylor C. (2001). School choice impacts: what do we now? Educational Researcher, 30(7), 18-23.

Government Bill 1990/91:85 Växa med kunskaper. [Growing with knowledge] Stockholm.

Government Bill 1991/92:95 Om valfrihet och fristående skolor. [About freedom of choice and independent schools] Stockholm.

Harvey, D. (2005). A brief history of Neoliberalism. Oxford: Oxford University Press.

Hatcher, R. (1998). Class differentiation in Education: Rational choices? British Journal of Education, 19(1), 5-24.

Hjort, T., Hjärpe, T. \& Panican, A. (2013). Rådgivare, vägledare och mäklare: om grundskolans roll och betydelse för gymnasievalet. [Adviser, counselor and 'broker'. On the role of the elementary school the choice

NJSR - Nordic Journal of Social Research 
of upper secondary school]. In A. Persson \& R Johansson (Eds.), Vetenskapliga perspektiv på lärande, undervisning och utbildning $i$ olika institutionella sammanhang- utbildningsvetenskaplig forskning vid Lunds universitet [Scientific perpsectives on learning, teaching and education in different institutional contexts: research on educational science at Lund University] (pp. 177-194). Lund: Institutionen för utbildningsvetenskap, Lunds universitet

Hohnen, P., \& Hjort, T. (2009). 'Citizens-as-consumers': A discussion of emerging new forms of marginalization in the Nordic Welfare States. European Journal of Social Security, 3(11), 271-290.

Hvinden, B., \& Johansson, H. (2007). Citizenship in Nordic welfare states. London: Routledge.

Johnsson, M. (2004). Kontrasternas rum. [The room of contrasts] Umeå: Umeå universitet.

Kallstenius, J. (2009). Segregation och skolvalfrihet i Stockholm. [Segregation and school choice in Stockholm] In G. Graninger \& C. Knuthammar (Eds.) Samhällsbyggande och integration [Community planning and integration] (pp. 27-40). Linköping: Linköpings universitet.

Kautto, M., Fritzell, J., Hvinden, B., Kvist, J., \& Uusitalo, H. (Eds.). (2001). Nordic welfare states in the European context. London: Routledge.

Kenway, J., Bigum, C., Fitzclarence, L., Collier, J. \& Tregenza K. (2007). New education in new times. In S. J. Ball, I. F. Goodson \& M. Maguire (Eds.) Education, globalization and new times (pp. 1-19). London: Routledge.

Kildal, N. \& Kuhnle, S. (2005). The Nordic welfare model and the idea of universalism. In Normative Foundations of the Welfare State, N. Kildal \& S. Kuhnle (Eds.). London: Routledge.

Kjellman, A-C. (2001). 'Hurra för valfriheten!' - men vad ska vi välja? ['Hurray for freedom of choice!': but what should we choose?] Stockholm: HLS.

Kvist, J., Fritzell, J., Hvinden, B. \& Kangas, O., (Eds.). (2012). Changing social equality: the Nordic welfare model in the 21st century. Bristol: Policy Press.

Lister, R., Williams, F., Anttonen, A., Bussemaker, J., Gerhard, U., Heinen, J., Johansson, S., Leira, A., Siim, B., Tobio, C., \& Gavanas, A. (2007). Gendering citizenship in western Europe-new challenges for citizenship research in a cross-national context. Bristol: Policy.

Lund, S. (2006). Marknad och medborgare [Market and citizens]. Växjö: Växjö University Press.

- - . 2007. Valfrihet och konkurrens: Utvecklingstendenser inom gymnasieutbildning. [Freedom of choice and competition: Tendencies

NJSR - Nordic Journal of Social Research

Vol. 5, 2014 
of development within the upper secondary level education] Pedagogisk Forskning i Sverige, 12(4), 281-300.

Marshall, T. H. (1992). Citizenship and Social Class. In T. H. Marshall \& T. Bottomore (Eds.), Citizenship and Social Class (pp. 1-53). London: Pluto Press.

Mitchell, K. (2003). Educating the national citizen in neoliberal times. Transactions of the Institute of British Geographers, 28(4), 387-403.

Norén, L. (2003). Valfrihet till varje pris. [Freedom to choose at all cost] Göteborg: BAS.

Norén, L. (2010). Public sector consumerism. In K. M. Ekström (Ed.) Consumer behaviour: a Nordic perspective (pp. 153-165). Lund: Studentlitteratur.

Offer, A. (2006). The challenge of affluence. Oxford: Oxford University Press.

Olofsson, J. (2010). Krisen i skolan: utbildning i politiken och i praktiken. [The crisis in school: the politics and practise of education] Umeå: Boréa.

Olofsson, J. \& Panican, A. (2008). Ungdomars väg från skola till arbetsliv: nordiska erfarenheter. [Youths' transition from education to work: experiences from the Nordic countries]. Köpenhamn: Nordiska Ministerrådet.

Panican, A. (2007). Rättighet och Rättvisa - användbarhet av rättighet och rättvisa $\mathrm{i}$ sociala projekt. [Rights and justice- the usefulness of rights and justice in social projects] Lund: Socialhögskolan, Lunds universitet.

Panican, A. (2013). The Growing Emphasis on Social Citizenship in Nordic Education: Inducing New Social Risks While Trying to Alleviate Them. In I. Harsløf \& R. Ulmestig (Eds.) Changing Social Risks and Social Policy Responses in the Nordic Welfare States (pp. 92112). Basingstoke: Palgrave Macmillan.

Peters, M. (2001). Valfrihet på de svagas bekostnad. [Freedom of choice at the expense of the weak]. Pedagogiska Magasinet, 1, 36- 41.

Ravitch, D. (2010). The death and life of the great American school system. New York: Basic Books.

Reay, D., \& Stephen J. B. (1997). Spoilt for choice: the working classes and educational markets. Oxford Review of Education 23(1), 89-101.

Richardsson, G. (2004). Svensk utbildningshistoria. [Swedish educational history] Lund: Studentlitteratur.

Roberts, N. C. (2008). The age of direct citizen participation. New York: Sharpe. 
Skawonius, C. (2005). Välja eller hamna. [Choosing or ending up] Stockholm: Pedagogiska institutionen.

Svallfors, S. (2004). Class, Attitudes and the Welfare State: Sweden in Comparative Perspective. Social Policy \& Administration, 38(2), 119138.

Swedish Government Official Report 1997:121 Skolfrågor: om skola i en ny tid. [School issues: about school in a new era] Stockholm: Fritzes.

Swedish Government Official Report 2000:39 Välfärd och skola. [Welfare and school] Stockholm: Fritzes.

Szebehely, M., \& Trygdegård, G-B. (2007). Omsorgstjänster för äldre och funktionshindrade - skilda villkor, skilda trender. [Care services for elderly and disabled - different conditions, different trends] Socialvetenskaplig Tidskrift, 14(2-3), 197-219.

The Swedish National Agency for Education 2011. http://www.skolverket.se/2.3894/in_ english

Trentmann, F. (2007). Citizenship and consumption. Journal of Consumer Culture, 7(2), 147-158.

Voet, R. (1998). Feminism and citizenship. London: Sage.

Wagner, A. (2004). Redefining citizenship for the 21st century. International journal of social welfare, 13(4), 278-286.

Vinnerljung, B., Berlin, M. \& Hjern, A. (2010). Skolbetyg, utbildning och risker för ogynnsam utveckling hos barn. [School-grades, education and risks for a disadvantageous development]. In Social rapport 2010 (pp. 228266). Stockholm: Socialstyrelsen.

Westerhäll, V. L. (2002). Den starka statens fall? En rättsvetenskaplig studie av svensk social trygghet 1950-2000. [The fall of the powerful state? A jurisprudential study of social security in Sweden 1950-2000]. Stockholm: Norstedts Juridik.

Young, T. W., \& Clinchy, E. (1992). Choice in public education. New York: Teachers College. 